\title{
Consumers' Attitude towards Branded Apparels: Gender Perspective
}

\author{
Namita Rajput (Corresponding author) \\ Associate Professor, Department of Commerce \\ Sri Aurobindo College, University of Delhi, Malviya Nagar, Delhi 110017, India \\ E-mail: namitarajput@gmail.com
}

Subodh Kesharwani

Assistance Professor, School of Management Studies

Indira Gandhi National Open University, Delhi, India

E-mail: subodhkesharwani@gmail.com

Akanksha Khanna

Research Scholar, Indira Gandhi National Open University, Delhi, India

E-mail: akanksha.kh@gmail.com

Received: January 31, 2012

Accepted: February 20, 2012 Published: April 1, 2012

doi:10.5539/ijms.v4n2p111

URL: http://dx.doi.org/10.5539/ijms.v4n2p111

\begin{abstract}
The relationship between consumers' decision-making styles and their choice between domestic and imported brand clothing is investigated using a sample of Indian consumers. The objective of this paper is to gauge the factors affecting purchase decision taking gender perspective as base. Empirical findings are calculated using survey technique and chi square test with a sample of 320 participants in Delhi and NCR. The objective of this paper is to analyze the significance of demographic profile of consumers affecting the purchase decision of branded garments and to observe from gender perspective the consumer awareness about different apparel brands available in the Indian market and also to find out whether there is a significant difference in total expenditure on branded apparels done by males vis- a - vis females. The results exhibit no significant differences in the brand awareness, shopping frequency and shopping expenditure between males and females.
\end{abstract}

Keywords: Private labels, Shopping behavior, Branded apparels, Fashion, Gender discrimination, Survey, Loyalty

\section{Introduction}

\section{"Clothes market a man"}

The Indian textile and apparel industry is the largest foreign exchange earner for the country. It is also the second largest employment provider after agriculture and plays a key role in the development of the economy. This industry profile on the 'Textile and Apparel Sector in India' provides a gainful insight of the industry. The fashion industry is the fastest growing industry in the world. From the last few decades, the fashion industry in India has been experiencing an explosion due to considerable dynamic nature which increases fashion consciousness among consumers. Everyone has a separate and elegant fashion sense which is mainly related to the apparels throughout the world. Apparels define the personality, education, behavior and the way of thinking of the people. It is substantial to note that Indian fashion consumers will set the global fashion trends in the coming era. Currently, all international brands are found in India. Indian fashion industry has progressed from emerging stage to successful blooming industry today. Indian apparel sales are expected to reach an estimated $\$ 25$ billion this year, having grown in excess of $10 \%$ over the past 5 years (Note 1) — a growth rate faster than that of the overall India retail market - and the curve is expected to continue. In India, apparel is the second 
largest retail category (behind food and groceries), representing approximately $10 \%$ of the total market (Note 2), e.g. Benetton recently hit $\$ 100$ million in sales in India, and is targeting \$250 million within the next 3-4 years, largely by targeting smaller cities, which are already contributing about $20 \%$ to the company's growth and growing much more quickly than in the larger markets (Note 3). India is also a manufacturer and exporter of international brands for clothes like Gap, Tommy Hilfiger, Espirit, Wills Lifestyle, Peter England, Allen Solly etc, after china and Bangladesh. India's textile and apparel industry, including domestic and exports, is expected to grow from Rs 3.27 lakh crores to Rs 10.32 lakh crore by 2020, says a new research report by Technopak Advisors, a leading management consultancy. It estimates that by 2015, the overall Indian apparel industry would be worth Rs. 2.88 lakh crores and the organized market share will be $25 \%$ of this. Therefore, one can say that the branded apparel market which is a major chunk of the organized market will be around Rs. 55,000-60,000 crores (Note 4).

There are numerous fashion designers of India which have distended into famous brands not only in the country but in the world which has given more improvement to the Indian fashion industry. Consumers' attitude is changing with the present scenario, as the hoisting of tailoring costs and comparatively less charges of branded outfits; they are increasingly being attracted towards ready-mades. Readymades of specific brands have become not only a status symbol; these have brought a more latest style in offices as much as in social circles. According to Fashion Design Council of India (FDCI), that apparels created by Indian designers are going to play a major role in the growth of the apparel industry in the next few years. These changes will have far-reaching implications for designers, manufacturers, and retailers targeting the Indian apparel market. Spanish fashion giant Inditex (Zara) has announced plans to enter India this year. Fast Retailing (Uniqlo) has pegged 2012 for market entry. The growth rate of the fashion market as per consumers' attitude for branded apparels in future that would increase drastically by more than $10-15 \%$ as compare to past in just 10 years (table 1).

Traditionally, Indians preferred dresses stitched by local tailors catered exclusively to local demand. The growing awareness of brands since 1980s and the convenience offered by ready-to-wear garments were largely responsible for the development of the branded apparel industry in India (Indian Retail Report 2010). Other factors affecting to its growth are considered as better purchasing power in the hands, access to fashion trends outside the country, and the superior quality of fabrics available in the fashion market. 1990s witnessed a drastic change in the overall economic environment of the country which is described liberal trade and new investment policies. It was seen the effects of such liberalized polices in the clothing industry also. After liberalization of Indian economy, there emerged more than 100 leading brands that jostled for consumer mind space. Today, Indians are more inclined than consumers in other markets to buy apparel for a specific purpose. Indeed, 38 percent of Indian respondents to a recent McKinsey study said they were highly likely to buy apparel for special events, a significantly higher proportion as compare to Brazil (5\%), Russia (3\%) or China (6\%). The growth of the Indian and global fashion designers has encouraged the branded apparel market additionally. Designers do annual business of $\$ 250$ million. Formerly, readymade market was restricted to some limited extant only like, baby dresses and shirts, but currently, it has extended to all kinds of outfits and fashion clothing for men and women also.

In the perspective of clothing, people express themselves through consumption in an innumerable ways. Similarly, executives determine the consumers' perception regarding a particular product and brand due to the skill of communication with customers differently. In gender perspective, for building individuality, a reasonableness of attainment and recognition for fashion conscious people, brands are perceived essentially in separate outlook the information for which can be made available through market segmentation in which analysis can be done in a profound way to find out differences in shopping behavior.

Market Segmentation is defined as the process of dividing a market into district subsets of the consumers with common needs or or characteristics and the selecting one or more segments to target with a distinct marketing mix. Segmentation studies are designed to discover the needs and wants of the specific groups of the consumers so that the specialized goods and services can be developed and satisfy each groups need.The purpose of this research is to investigate buying behavior which constitutes expenditure, independence and frequency as regards males and females. In this competitive era marketer must be fully aware about the customer needs distinctly and separately as two groups males and females as regards what are they expecting from a brand, how they differ in their buying behavior, factors which push them to purchase a particular brand, their total outlay, shopping frequency etc to attain a competitive edge. This vital information can help the companies to formulate the strategies as per the customer needs \& deliver them the products which consumer want from the company which will be profitable for the company embedding gender perspective. Retailers and marketers should understand the immense diversity among consumers if they are to market apparel accurately and successfully. 
The following paper is divided into six sections. Section 1 i.e. the present section gives the introduction of the paper giving the contemporary position of apparel industry in India. Section 2 gives extensive review of literature of studies done in India and overseas. Section 3 explains the conceptual framework of Indian apparel industry in respect of gender discrimination and research objectives. Chapter 4 elaborates data and methodology used in paper to achieve the objectives of the study. Section 5 exhibits analysis and interpretation of results derived from the study. Section 6 concludes the paper.

\section{Review of Literature}

In accordance with assorted definitions of brands, two approaches of defining a brand are derived. The traditional one is a practical view which articulates a brand as a product identifier, including the source of the product (Aaker, 1991). According to him, "a brand is a distinguishing name and/or symbol which intended to identify the goods, services of either one seller or group of sellers and to differentiate those goods or services from those of competitors". Another approach, as holistic view, presents a brand as more than just the product (Styles \& Ambler, 1995). This defines brand as the promise of the bundles of attributes that someone buys which provides satisfaction and attributes that make up a brand" (Ambler, 1992). It is seen that brands describe personality of the users with particular lifestyle. It also helps to convey a sense of belonging to a specific social group (Murphy, 1990). He perceives brand not only as the actual product, but also the unique property of a specific owner. It has been developed over time as a set of values and attributes which significantly differentiate products of similar appearance. Clothing is to form an integral part in the enactment of social encounters and also seen as a very important channel of non-verbal communication (Noesjirwan \& Crawford, 1982). Clothing is used as a code, which allows messages to create an understanding, selectively (Auty \& Elliott, 1998). They also define that opinions of brand users have difference for identical brands within a product category.

One of the major components of brand knowledge is brand awareness, which is taken as the ability of a potential buyer to recognize or recall that a brand is a member of a certain product category (Rossiter \& Percy, 1987 and Aaker, 1991). It is created by an increase in the acquaintance of the brands through repeated exposure, strong associations and consumption cues (Keller, 2003). Brand knowledge defined as brand information that relates with the brand stored in a consumer memory. Brand knowledge can be categorized in two aspects: brand awareness and brand image (Keller, 2004). Brand awareness is the strength of brand which is reflected by the identification of that brand under several conditions. It is a combination of recognition and recall performance. Brand image is consumers' perception about the brand. Some other studies focused on the same issues, as, Lingle et al., 1979; Riskey \& Dwight, 1979; Holbrook \& Kim, 1985; Zeithaml, 1988; Veeck \& Burns, 1995; McEnally et al., 1999 and Suri \& Monroe, 2001. Customers depend on their brand knowledge to decide among competing brands which determines their thinking and response to different stimuli regarding a particular brand (O'Cass, 2000 and O'Cass \& Lim, 2002). Thus, a consumer's decision to buy a product or service is the result of interplay of many forces or stimuli (Kotler \& Armstrong, 2006). While other studies conducted on consumer behaviour can be cited as, Anderson \& Stephen, 1963; Lichtenstein et al., 1993; Auty \& Elliott, 1998; Robertson, 2000; Kim et al., 2002; Grundey, 2006 and Jairam, 2009. But there are not enough studies which considered gender issue in respect of consumer attitude and branded apparels existing in fashion industry, except few ones (Taylor \& Cosenza, 2002; Alexander, 2005 and Nam et al., 2007). Therefore, the current study enlightens the relative concept.

\section{Conceptual Framework and Research Objectives}

\subsection{Conceptual Framework}

At present, the textile and apparel industry is one of the leading segments of the Indian economy. It is the largest source of generating foreign exchange and creating employment opportunities for India. 4\% of gross domestic product (GDP), $20 \%$ of industrial output, and surplus of $30 \%$ of export earnings are produced through this industry. It employs about 38 million people as a largest source of industrial employment in India which is estimated to 12 million for the year 2010. India's apparel retail market is obtainable to touch Rs 4.70 lakh cr by 2020. The significance of the textile economy is $\$ 37$ billion and its share is about $5.9 \%$ of the global market. The rising revenue is $\$ 85$ billion with its encouraging export value of $\$ 50$ billion. The garments industry categorizes itself into many segments: formal wear and casual wear separated for males and females, women's dresses, men's outfits and kids wear, suits, trousers, jackets and blazers, shirts, sportswear, t-shirts, denims, neckwear, undergarments (men and women), night wears, woolens, saris etc. The Indian clothing market is estimated at Rs. 430 billion with menswear segment accounting for $46 \%$, share of women's is counted at $36 \%$ and kid's clothing can be tagged at $17 \%$. The Indian branded garment market is estimated at over Rs. 185 billion, accounts for $25 \%$ of the Rs. 745 billion readymades market. Following the entry of several new brands, the branded segment has 
grown at $25 \%$ annually. This represents a shift from unbranded to the branded segment which is majorly a result of the changing patterns of consumer buying as they become increasingly demanding, more aware and more affluent.

Fashionable apparel is a product that is consumed publicly and possesses public meaning. It realizes several societal needs of the consumer to express and build their distinctiveness and self-image to astound others. The products and apparels are bought with different mindset, outlook, and sensitivity according to different age groups of people (Pecheux \& Derbaix, 1999). Efficacy, manifestation, financial worth and the ability to convey status, success and prestige are other aspects to finalize the product and brand purchase. It can be satisfied through the purchase of high profile branded \& high priced apparel. Pricing of a brand also matters as, high priced apparel is a product that has a high potential for symbolic meaning. However, attitudes are evolving as advertising helps in improving living standards foster greater brand consciousness and fidelity. There is no shortage of opportunities for companies that take the time to understand this complex game in the market.

There are numerous studies on the links between consumer's personality traits and their buying behaviors for over 40 years. Gender issue also an upgrading aspect of such kind of research recently, as males and females are having their own perceptions and attitudes towards each aspect of life and is inadequately research area. Branding was introduced to differentiate homogenous products such as clothing. Brand names or branding create trust, identify products and services, and are more of a psychological assurance than a tangible item. It builds an image of the product which is a sort of message devoted to potential customer. The psychological behavior of customer defines conscious and unconscious elements that create relationship between brand and user (Blery \& Gilbert, 2006). Consumers seem to be associated with a products, promises and brands through their own perception about their needs, aspiration and self. Hence, a marketer has to correctly read the buyer's behavior to a particular response (ICMR, 2003). Every person has his/her separate standards of judgments which reflect in decisions. This study will consider the personal factors, like age, income, education, occupation, lifestyle, personality and self concept, influencing the buying decision of consumers with respect of gender discrimination.

Personal factors modify how a male or female is perceived and the most important personal factor is the consumer personality. Personality is a dynamic concept which changes with the life has gone, describing the growth and development of human psychological setup which also differ on gender aspect. Most of the time products project a "personality" or an image that has an appeal to the consumer, with which consumer (he or she) can relate to. The point that is important from marketing point of view is, given the consumer's different and distinct personality traits concerning gender issue, the marketer should be able to identify these differences and its influence on the buying behavior. Along with many basic differences of their personality, the personal factors which affect the perception of a consumer are the occupation, economic status, age, education and social life. The new brand or style in outfit can be perceived as a necessity, luxury or a super luxury product depending upon the awareness and attitude towards particular item which depend on anyone of the above or the association of two or more.

Many studies have given insights about gender difference in building relationships with brands. The results revealed by these studies magnify the role of women in judgment of a brand and consider women as an active partner than men in buying behavior. But there are major drifts in present scenario in which there is a changed site of men concerning the current fashion and also knowing the latest trends as far as buying behavior is concerned. Product involvement differs as per the demographic profile of people which is the major factor influencing purchase decision of the product also indicating gender perspective. Therefore, it is imperative to judge the gender prospect of targeting consumers with their demographic characteristics because magnitude of brand knowledge may impact consumers' purchase decision differently depending upon their demographic distinctiveness.

\subsection{Research Objectives}

Purchase decision is facilitated by having a comprehensive knowledge of the brand which helps in evoking positive effects towards the brand, as these days people don't buy the product they buy images (brands). It influences brand choice, preferences and intention to purchase of consumers. Therefore, it is indispensable for a marketer to comprehend about the perceptions of consumers for a brand which impact the purchase decision embedding gender perspective. The purpose of the study is to examine how brand awareness influences an outlook of the consumer about various brands which leads to take purchase decision. Objectives of the study are:

1) To analyze the significance of demographic profile of consumers affecting the purchase decision of branded garments. 
2) To observe consumer awareness about different apparel brands available in the Indian market in gender perspective.

3) To find out whether there is a significant difference in total expenditure on branded apparels done by males vis- a - vis females.

Following hypotheses are formed to test the hypotheses:

$\mathbf{H}_{\mathbf{0}}$ : Males and females are not having differences in their brand awareness.

$\mathbf{H}_{1}$ : Males and females carry out differences in their brand awareness.

$\mathbf{H}_{\mathbf{0}}$ : Males are equally interested to go for shopping as females.

$\mathbf{H}_{2}$ : Males are less interested to go for shopping rather females.

$\mathbf{H}_{\mathbf{0}}$ : Males spend excess money during shopping than females.

$\mathbf{H}_{3}$ : Males spend less or equal amount of their income to females.

\section{Data and Methodology}

\subsection{Data}

In this paper, total 320 respondents are participated fairly with the age group of 15-40. Participants, which included males (162 or 50.6\%) and females (158 or 49.4\%), are varying from student to professional or job seekers highlight the diversity of the survey. The sampling technique used for the paper is Random within Quota sampling by age and gender. Consumers with different demographic characteristics may differ in the amount and type of effort they put into shopping and the way they make purchase decisions. There are individual differences in information search process have been found to be related to demographic characteristics. Research has introduced relation among search effort age, gender and economic conditions.

\subsection{Methodology}

A survey was conducted by a carefully developed questionnaire, to investigate the brand awareness and attitude of the consumers towards selected brands of apparel industry existing in India. A combination of both open-ended and close-ended questions was asked to analysis the pre-determined objectives. Further, to test consumer perception of various brands, a rating question was incorporated wherein the consumers were required to rate each mentioned brand and their various attributes. The tool also included a part dedicated to psychographics so as to access consumer attitude towards branded clothing. Another method is also used for having more clarity of the results i.e. Chi-square test. It also involves use of secondary sources such as web and other research articles Printed by various financial institutions and other journals and magazines.

\section{Analysis and Interpretation}

Hypothesis 1:

$\mathrm{H}_{0}$ : Males and females are not having differences in their brand awareness.

$\mathrm{H}_{1}$ : Males and females carry out differences in their brand awareness.

It is concluded that on a whole males and females are not carrying differences in their brand awareness as in majority cases the calculated value is greater than the table value for 1 degree of freedom at $5 \%$ level of significance (see table 2, table $3 \&$ fig 1 ). Hence the study accepted the null hypothesis and rejected the alternative one which says that males and females are not having differences in their brand awareness. It's all about their way of living only. So that, the study confirmed the fact that awareness about the branded apparels is independent attribute which has no impact of gender discrimination.

Hypothesis 2:

$\mathrm{H}_{\mathrm{o}}$ : Males are equally interested to go for shopping as females.

$\mathrm{H}_{2}$ : Males are less interested to go for shopping rather females.

Since the significance value is greater than 0.05 hence we accept the null hypothesis and reject the alternate hypothesis (table $4 \&$ table 5). The proposed null hypothesis states that males are equally interested to go for shopping as often as females (graphical presentation in fig 2). Though it has been observed that females are fond of shopping and males prefer staying at home rather "wasting time" on shopping. But, in the present scenario, the study highlights that the trend is changing smoothly with time. Nowadays males are equally fond of going on shopping with their female companions similar to the fact that current times have metro sexuality as a rage 
among the males. Another cause of this changing trend is the availability of a wide range and variety in the shopping malls designed for men's wear.

Hypothesis 3:

$\mathrm{H}_{\mathrm{o}}$ : Males spend excess money during shopping than females.

$\mathrm{H}_{3}$ : Males spend less or equal amount of their income to females.

Since the significance value is greater than 0.05 hence we accept null hypothesis and reject the alternate hypothesis (table 6 , table $7 \&$ fig 3 ). The null hypothesis states that males spend excess money as compare to their female counterparts. Females by nature are more savings oriented. They had to take care of the household, so they need to be more careful about expenses that might eat away their monthly savings. Hence for the same reason, at times, females are required to postpone their idea of shopping for later times. On the converse, men spend more of their income as prestige comparatively to female consumers which is of great importance to them. Women consider price also before taking the purchase decision while men hardly care about the price of the product. Therefore, there are many reasons for this difference, but lastly it is confirmed that males spend excess money during shopping than female consumers.

\section{Conclusion}

The preference of consumers for readymade outfits even for branded apparels is fast changing caused by the creation of personality and status with the quality and comfort they deliver. Due to the increased awareness and consciousness, people are ready to spend any price for comfort and quality. Intense era provide high quality materials and lot of variety in Indian garment market to satisfy the desire of customers. The customers are also utilizing the opportunity too. The results confirm that Indian people have become highly brand conscious presently. Hence, brand image is a not a significant factor in choosing the product or brand to buy. There are other aspects like, quality, comfort, expectations and demographic characteristics are also influence to the purchasing decision that dominate the purchase decision of males and females. From the analytical introspection it is evident that the gender differences do exist with respect to build attitude towards fashionable apparels and brands. Further, the variation in age and income is not significant as consumers preferred brands or outfits irrespective of that. Allen Solly tops the minds of the customers followed by Van Heusen and Raymonds which refers to the maximum frequency of recalling the brands. These are the most familiar and favourite brands also among brand aware consumers, specifically in context of India.

Finally, males and females are not having any significant differences in their brand awareness, shopping frequency and shopping expenditure. Males are equally interested to go for shopping as females along with they spend excess money during shopping than their female counterparts. Frequency of males going for shopping with their companions has increased over times and has reached almost at par with that of females. Attitude of males towards clothing varies from that of females. There are two factors are found during measuring attitude of consumers towards branded apparels, Intrinsic Pleasure and Prestige and Status. Intrinsic Pleasure included pleasure and significance, in the same way, Prestige and Status integrated status, impression and acceptance of the branded products.

\section{References}

Aaker. (1991). Managing Brand Equity: Capitalizing on the Value of a Brand Nam. The Free Press. New York, NY.

Alexander. (2005). Clothing fit preferences of young female adult consumers. International Journal of Clothing Science and Technology, 17(1), 52-64.

Ambler. (1992). Need-to-know Marketing. Century Business. London.

Anderson, Stephen. (1963). Effects of Concomitant Verbal Recall on Order Effects in Personality Impression Formation. Journal of Verbal Learning and Verbal Behavior, 2 (5-6), 379-91. http://dx.doi.org/10.1016/S0022-5371(63)80039-0

Auty, Elliott. (1998). Fashion involvement, self-monitoring and the meaning of brands. Journal of Product \& Brand Management, 7(2), 109-123. http://dx.doi.org/10.1108/10610429810216874

Blery, Gilbert. (2006). Factors Influencing Customer Retention in Mobile Telephony: A Greek Study. Transformations in Business \& Economics, 5(2), 178-188.

Carlston. (1980). The Recall and Use of Traits and Events in Social Inference Processes. Journal of Experimental Social Psychology. 16 (July), 303-28. 
Grundey. (2006). Delineating Values, Emotions and Motives in Consumer Behaviour: An Interdisciplinary Approach. Transformations in Business \& Economics, 5(2), 21-46.

Holbrook, Kim. (1985). Quality and Value in the Consumption Experience: Phaedrus Rides Again in Perceived Quality. Jacob Jacoby and Jerry Olson, eds. Lexington. MA: Lexington Books, 31-57.

ICMR. (2003). A note on the Branded Apparel Industry in India - Center for Management Research of India. [Online] Available: www.icmrindia.org/casestudies/catalogue/Business\%20Reports/BREP018.htm

Indian Retail Report. (2007). [Online] Availabe: www.indiaretailing.com/retail-report.asp

Jairam. (2009). Indian textile, apparel industry now part of global supply chain. Business wire India. [Online] Available:

http://www.financialexpress.com/news/indian-textile-apparel-industry-now-part-ofglobal-supply-chain-jairam/4 15582/0, posted on 27-01-2009.

Keller. (2003). Strategic brand management: Building, measuring and managing brand equity (2nd ed.). New Jersey: Pearson Education Inc.

Keller. (2004). Strategic Brand Management. Pearson Education.

Kim et al. (2002). Cross-Cultural Consumer Values, needs and purchase behavior. Journal of Consumer Marketing, 19(6), 481-502. http://dx.doi.org/10.1108/07363760210444869

Kotler, Armstrong. (2006). Principles of Marketing. Prentice Hall of India.

Lichtenstein et al. (1993). Price perceptions and consumer shopping behaviour: A field study. Journal of Marketing Research, 30(2), 234-245. http://dx.doi.org/10.2307/3172830

Lingle et al. (1979). Retrieval Selectivity in Memory-Based Impression Judgments. Journal of Experimental Social Psychology, 23 (March), 93-118.

McEnally et al. (1999). The Evolving Nature of Branding: Consumer and Managerial Considerations. Academy of Marketing Science Review, 1.

Murphy (1990). Assessing the value of brands. Long Range Planning, 23(3), 23-29.

Nam et al. (2007). The fashion-conscious behaviours of mature female consumers. International Journal of Consumer Studies, 102-108.

Noesjirwan, Crawford. (1982). Variations in perception of clothing as a function of dress from and viewers' social community. Perceptual and Motor Skills, 54, 155-163. http://dx.doi.org/10.2466/pms.1982.54.1.155

O'Cass (2000). An assessment of consumers' product, purchase decision, advertising and consumption involvement in fashion clothing. Journal of Economic Psychology, 21, 545-576. http://dx.doi.org/10.1016/S0167-4870(00)00018-0

O'Cass, Lim. (2002). Understanding the younger Singaporean consumers' views of Western and Eastern brands. Asia Pacific Journal of Marketing and Logistics, 14(4), 54-79. http://dx.doi.org/10.1108/13555850210764954

Pecheux, Derbaix. (1999). Children and Attitude toward the Brand: A New Measurement Scale. Journal of Advertising Research, July-August, 19-27

Riskey, Dwight. (1979). Verbal Memory Processes in Impression Formation. Journal of Experimental Psychology: Human Learning and Memory, 5(3), 271-81. http://dx.doi.org/10.1037/0278-7393.5.3.271

Robertson. (2000). Creating world class brands: The encyclopedia of brands and branding. Johannesburg: Imagination Corporation.

Rossiter, Percy. (1987). Advertising and promotion management. New York. McGraw-Hill Book Company.

Srinivasan. (1979). Network Models for Estimating Brand Specific Effects in Multi-Attribute Marketing Models. Management Science, 25. 11-21.

Styles, Ambler. (1995). Brand Management. Financial Times Handbook of Management. Pitman, London, 581-93.

Suri, Monroe. (2001). The effect of need for cognition and trait anxiety on price acceptability. Psychology \& Marketing, 18(1), 21-43. http://dx.doi.org/10.1002/1520-6793(200101)18:1<21::AID-MAR2>3.0.CO;2-T

Taylor, Cosenza. (2002). Profiling Later Aged Female Teens: mall shopping behavior and clothing choice. Journal of Consumer Marketing, 19(5), 393-408. http://dx.doi.org/10.1108/07363760210437623 
Veeck, Burns. (1995). An investigation of the use of price quality schema by urban Chinese consumers. Advances in Consumers Research, 22(1), 297-302.

Zeithaml. (1988). Consumers perceptions of price, quality, and value: a means end and synthesis of the evidence. Journal of Marketing, 52(3), 2-22.

\section{Notes}

Note 1. According to the India Ministry of Textile, apparel sales for 2008 were $\$ 20$ billion; Datamonitor.

Note 2. How Half the World Shops (McKinsey propriety market research).

Note 3. Economic Times, April 15, 2010, "Benetton India revenue likely to touch $\$ 250 \mathrm{~m}$ in 4 years".

Note 4.

http://www.fashionunited.in/news/fashion/indias-apparel-retail-to-touch-rs-470-lakh-cr-by-2020-080920101106

Table 1. Apparels purchases through different channel and its growth rate

\begin{tabular}{|l|c|c|}
\hline Consumption route & Apparel consumption share & Annual growth rate \\
\hline $\begin{array}{l}\text { Organized apparel } \\
\text { brands }\end{array}$ & $5 \%$ & $15 \%$ \\
\hline $\begin{array}{l}\text { Unorganized apparel } \\
\text { brands }\end{array}$ & $10 \%$ & $10 \%$ \\
\hline $\begin{array}{l}\text { Organized apparel } \\
\text { manufacturers }\end{array}$ & $5 \%$ & $10 \%$ \\
\hline $\begin{array}{l}\text { Outfits retail } \\
\text { channels }\end{array}$ & $60 \%$ & $3.5 \%$ \\
\hline $\begin{array}{l}\text { Designers \& } \\
\text { Boutique }\end{array}$ & $5 \%$ & $10-15 \%$ \\
\hline Tailoring & & $1-2 \%$ \\
\hline
\end{tabular}

Table 2. Gender vs. brand awareness

\begin{tabular}{|c|c|c|c|}
\hline S. No. & Brands & No. of males knowing the brand & No. of females knowing the brand \\
\hline 1 & Louis Phillipe & 128 & 120 \\
\hline 2 & Raymonds & 162 & 158 \\
\hline 3 & Allen Solly & 154 & 158 \\
\hline 4 & Excalibur & 102 & 106 \\
\hline 5 & Van Heusen & 144 & 114 \\
\hline 6 & Zodiac & 136 & 130 \\
\hline 7 & Peter England & 162 & 146 \\
\hline 8 & John Players & 140 & 142 \\
\hline
\end{tabular}

Note: Total No. of males $=162 \&$ females $=158$ out of 320 respondents 
Table 3. Chi-square tests for all brands

\begin{tabular}{|c|c|c|c|c|c|c|c|c|}
\hline & $\begin{array}{c}\text { Louis } \\
\text { Philliipe }\end{array}$ & Raymonds & $\begin{array}{c}\text { Allen } \\
\text { Solly }\end{array}$ & Excalibur & $\begin{array}{c}\text { Van } \\
\text { Heusen }\end{array}$ & Zodiac & $\begin{array}{c}\text { Peter } \\
\text { England }\end{array}$ & $\begin{array}{c}\text { John } \\
\text { Players }\end{array}$ \\
\hline Chi Square & $0.217 \mathrm{~b}$ & 0 & $4.004 \mathrm{~b}$ & $0.302 \mathrm{~b}$ & $7.174 \mathrm{~b}$ & $0.081 \mathrm{~b}$ & $6.394 \mathrm{~b}$ & $0.459 \mathrm{~b}$ \\
\hline Df & 1 & 0 & 1 & 1 & 1 & 1 & 1 & 1 \\
\hline Asym. Sig. & 0.644 & 0 & 0.081 & 0.587 & 0.571 & 0.779 & 0.086 & 0.503 \\
\hline
\end{tabular}

Note: $a$ Computed only for a $2 \times 2$ table and $b$ is different for all the brands.

Sig. value of Louis Philliipe has more than 0.05. The minimum expected count is 17.79.

Sig. value of Raymonds has 0; hence, no statistics are computed as AWARE_2 is a constant.

Sig. value of Allen Solly has more than 0.05. The minimum expected count is 19.92.

Sig. value of Excalibur has more than 0.05. The minimum expected count is 27.69.

Sig. value of Van Heusen has more than 0.05. The minimum expected count is 15.35.

Sig. value of Zodiac has more than 0.05. The minimum expected count is 13.36 .

Sig. value of Peter England has more than 0.05. The minimum expected count is 29.19.

Sig. value of John Players has more than 0.05. The minimum expected count is 19.41.

Table 4. Gender vs. shopping frequency

\begin{tabular}{|c|c|c|c|c|c|}
\hline Shopping & & Fortnightly & monthly & occasionally & Total \\
\hline \multirow{2}{*}{ Gender } & Male & 38 & 82 & 42 & 162 \\
\cline { 2 - 6 } & Female & 34 & 92 & 32 & 158 \\
\hline \multirow{2}{*}{ Total } & & 72 & 174 & 74 & 320 \\
\hline
\end{tabular}

Table 5. Chi-square test

\begin{tabular}{|l|c|c|c|}
\hline & Value & df & Asymp. Sig. (2-sided) \\
\hline Pearson Chi-Square & 1.051 & 2 & 0.594 \\
\hline Likelihood Ratio & 1.053 & 2 & 0.593 \\
\hline Linear-by-Linear Association & 0.125 & 1 & 0.730 \\
\hline N of Valid Cases & 320 & & \\
\hline
\end{tabular}

Note: $a 0$ cells $(.0 \%)$ have expected count less than 5 . The minimum expected count is 17.79 .

Table 6. Gender vs. shopping expenditure

\begin{tabular}{|c|c|c|c|c|c|c|}
\hline \multirow{2}{*}{$\begin{array}{c}\text { Spending/ } \\
\text { Gender }\end{array}$} & Male & 48 & 58 & 48 & 8 & 162 \\
\cline { 2 - 7 } & Female & 38 & 66 & 46 & 8 & 158 \\
\hline \multirow{2}{*}{ Total } & & 86 & 124 & 94 & 16 & 320 \\
\hline
\end{tabular}

Table 7. Chi-square tests

\begin{tabular}{|l|c|c|c|}
\hline & Value & Df & Asymp. Sig. (2-sided) \\
\hline Pearson Chi- Square & 0.838 & 3 & 0.844 \\
\hline Likelihood Ratio & 0.839 & 3 & 0.843 \\
\hline Linear-by-Linear Association & 0.153 & 1 & 0.699 \\
\hline N of Valid Cases & 320 & & \\
\hline
\end{tabular}

Note: $a 2$ cells $(25.0 \%)$ have expected count less than 5. The minimum expected count is 3.96. 


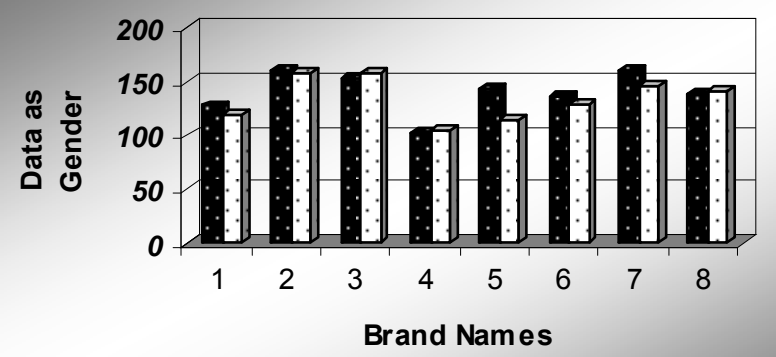

- No. of males know ing the brand $\square$ No. of females know ing the brand

Figure 1. Gender vs. brand awareness

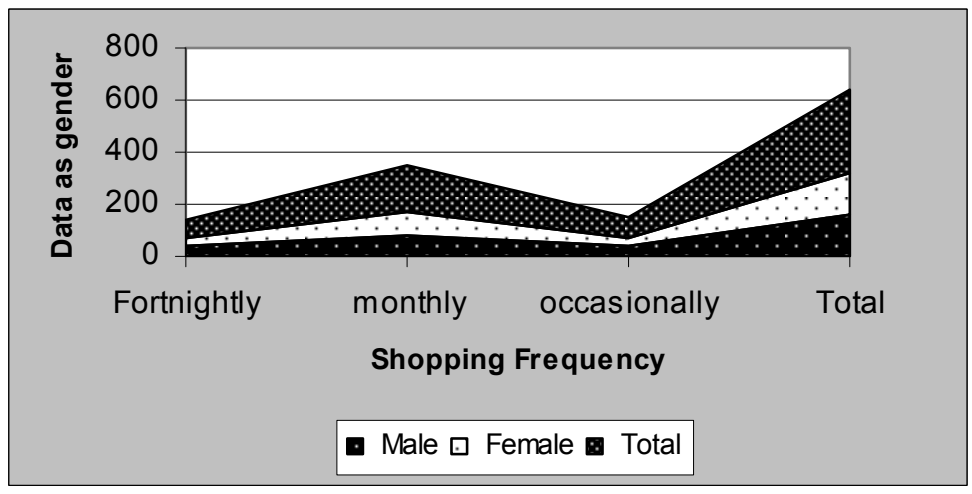

Figure 2. Gender vs. shopping frequency

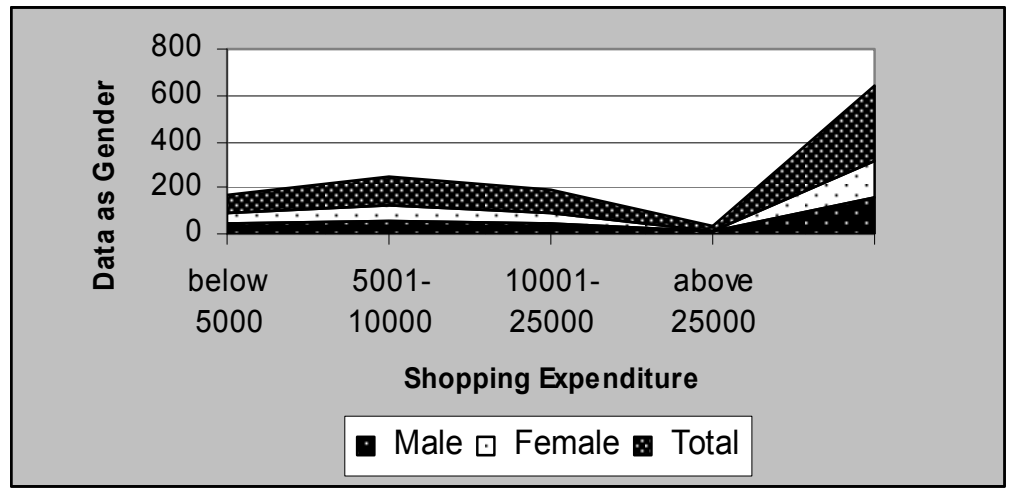

Figure 3. Gender vs. shopping expenditure 